\title{
Management of Forest Related Natural Resources through Participatory Approach
}

\author{
Haidar Ali ${ }^{1 *}$, Malik Muhammad Shafi ${ }^{2}$, Mahwish Siraj ${ }^{1}$ Himayatullah² and Aman Ullah ${ }^{1}$
}

${ }^{1}$ Ph.D. Scholar at Institute of Development Studies, Khyber Pakhtunkhwa, University of Agriculture, Peshawar, Pakistan

${ }^{2}$ Institute of Development Studies, Faculty of Rural Social Science, Khyber Pakhtunkhwa, University of Agriculture, Peshawar, Pakistan

\begin{abstract}
Topographic and climatic conditions of major parts of Khyber Pakhtunkhwa warrant special measures for management of natural resources to prevent degradation of land resources, conservation of forest related natural resources, optimization of resource use, provision of sustainable livelihood and alleviation of poverty. National rate of deforestation is around 7000 to 9000 hectares per annum in Khyber Paktunkhwa. Destruction of forests is more evident in certain areas of Khyber Pakhtunkhwa. To reverse this trend and to conserve natural resources, participatory approach has been suggested as an instrument at several national and international forums. The linchpin in the participatory approach is formation and mobilization of Village Development Committees (VDCs). These committees were formulated under Malakand Social Forestry Project. It was assessed through this research how much instrumental have been VDCs to mobilize communities. Results show there is some partial success. Still a lot is needed to improve the working of VDCs.
\end{abstract}

Keywords: Participatory approach; Pakistan; Sustainable livelihood

\section{Introduction}

Role of natural resources for sustainability of human life is very vital. Extinction of natural resources due to poor management means extinction of human life. Natural resources include land, water, air, forests, animals, plants, aquatic life, atmosphere, minerals, fossils and solar energy. In short, natural resources are wealth on which human well-being and survival ultimately depends. Like other types of capital, the stock of natural resources can be increased or diminished by human activity. Forests are an important natural resource.

Poverty alleviation through Natural Resources Management (NRM) has always been debatable and baffling issue in Pakistan. In context of forests management some scholars argue that poor residing near forests are the biggest enemy of forests trees therefore, to involve them in the natural resources management is not an easy task.

Pakistan is basically an agricultural country. Agriculture is still the largest sector of the economy. Majority of landowners is small and individualistic. About 86 percent of landowners have their land holdings below 12.5 acres [1,2]. With the passage of time, due to sub division of land holdings based on Islamic law of inheritance, number of small landholders and landless people is increasing overtime. Many small farmers finding it difficult to eke out their living exclusively from land are raring livestock to supplement their income. Some other small farmers have switched over to multiple employments; still some other farmers are getting out of agriculture. According to Shahid [3] about 100,000 of small farmers is leaving agriculture profession. Due to the above-mentioned reasons poverty is relatively higher in the rural areas as compared with urban areas [4].

To alleviate poverty and to provide sustainable livelihood to farming communities' management of forest related natural resources along with development of agriculture is equally important. For mankind, forests are an important source. They provide timber, firewood, food, fodder, medicines, water and recreation. However, forests are getting depleted and deforested at a very fast rate because the available forest resources cannot meet the expanding forest requirements of population growing at a very high rate. The situation is quite alarming in developing countries like Pakistan where there is already acute shortage of forest area. Only 4.8 areas are reported under forest while more than $60 \%$ is treated as wasteland. For a balanced economy and healthy environment, it is essential that every country should have 20 to $25 \%$ of its area under forests. Pakistan is forest deficient country with 4.2 million hectares of forest area out of 87.98 million hectares.

NRM is relatively new concept introduced in Pakistan. However, this trusted, tested and old age concept has produced substantial and concrete results in developing countries. NRM includes area like population, women programs, institutional development, community organization, land improvement, agriculture, horticulture, livestock improvement and environmental rehabilitation.

The NRM thus faces challenges of enabling communities to management their natural resources in order to achieve optimum utilization on sustainable basis. NRM aims at reducing losses and improving productivity by helping communities to identify and remove constraints and by increasing their access to more efficient technology.

At government level various approaches have been used to manage the natural resources. After creation of Pakistan, concerned departments were assigned to identify, design and implement various natural resource programs whether belonging to agriculture, forestry, livestock etc. All programs were centralized in nature.

Experience of last 20 years has shown that the "top down" approach has largely been failed to reach and benefit the poor. More recently an approach emphasizing people's participation has emerged as a possible alternative for promoting rural development. This program includes development of human resources and involvement of communities

*Corresponding author: Haidar Ali, Ph.D. Scholar at Institute of Development Studies, Khyber Pakhtunkhwa, University of Agriculture, Peshawar, Pakistan, Tel: +923339350722; E-mail: haiderkpk59@gmail.com

Received June 07, 2014; Accepted July 29, 2014; Published July 31, 2014

Citation: Haidar Ali, Shafi MM, Siraj M, Himayatullah, Ullah A (2014) Management of Forest Related Natural Resources through Participatory Approach. J Environ Anal Toxicol 4: 237. doi: 10.4172/2161-0525.1000237

Copyright: @ 2014 Haidar Ali, et al. This is an open-access article distributed under the terms of the Creative Commons Attribution License, which permits unrestricted use, distribution, and reproduction in any medium, provided the original author and source are credited. 
in management of natural resources. It is believed that rural environment can only be protected with relative collaboration of local population. One of the major concerns of this approach is to organize rural population through small scale village committee called village organizations (VO's) or Village Development Committees (VDCs). These VOs are designed to enable local population to participate in development of rural areas including management of natural resources.

One major factor of limiting success of Forest Department has been reported as centralized policies, resulting in lack of contact and coordination among local communities and government institutions. In the past, forest development schemes were implemented without the consent of the people.

To overcome this, Social Forestry Project, with the help of Netherlands government, was introduced in late 1980s. New approach emphasized the involvement of local communities in protection and replantation of forests in Malakand Agency and Swat areas. Village Development Committees (VDC's) were formed to enable people to participate in the development process. The same social forestry approach was extended in whole of Khyber Pakhtunkhwa in the late 1990s [4]. In this study an effort was made to investigate the working of this new approach. This study provides an insight to the advocates of participatory approach for NRM, working of VDC's in our socioeconomic and cultural environment. Insight can be gained for refining of participatory approach. Following are the objectives of the study.

In the past several approaches had been employed by various projects, organizations and institutions, dealing with poverty alleviation and natural resource conservation. In many cases poverty alleviation was incorporated in goals and objectives of the project, but emphasis was either on sectoral development or on general socio-economic development and the poverty alleviation did not get the projection and emphasis.

Various approaches followed in the past for implementation of the various projects, can loosely be categorized (Annex-I)

Objectives of the study:

1. To review NRM approaches tried in the past.

2. To review forest related activities/interventions introduced by Social Forestry Project (SFP).

3. To assess the role of VDC's in implementation of SFP interventions.

\section{Methodology}

The study was conducted in Malakand Agency of Khyber Pakhtunkhwa. Social Forestry Project was launched in this area in 1987 and it continued till 2003. Focus of the project was protection and rehabilitation of forest related natural resources through participatory approach. Village committees were formed in almost all villages to facilitate participation of local communities in natural resource development and management. Ten villages were randomly selected from the project area. From sampled villages respondents were also randomly selected. Respondents included both members of VDCs and non-members. Total number of respondents was 395. Out of these 215 were owner farmers and 180 were tenants. Data was collected through a pretested interview schedule. Activities undertaken by VDCS were investigated.

\section{Results and Discussion}

This section presents the results of the study. It gives the socioeconomic characteristics of sampled respondents, composition of
Village Development Committees (VDCs), and activities undertaken by VDCs, etc.

Respondents included land owners as well tenants. Age composition of both the categories is given in Table 1. The highest number of respondents was in the age group 45-54 years and the lowest number of respondents was in the age group "above 65 " years. This was true both for tenants as well owners. The percentage of respondents in various age groups is depicted in Table 1 these results are in line with Shahid [2].

Education of respondents is given in Table 2. On an average 24\% of respondents were illiterate and $76 \%$ were literate. Illiteracy was higher among tenants as compared with owners. Fourteen percent of owners and $39 \%$ of tenants were illiterate. More than $50 \%$ of respondents were matriculate or above matric level these results are in line with ADB [2].

Majority of respondents (47\%) were agriculturists followed by government servants (22\%) and businessmen (22\%). Detail of occupations of owners and tenants is given in Table 3 these results are in line with Asian Development Bank [2].

One of the major concerns of Social Forestry was to establish VDCs to enable people to participate in various natural resource management activities. All major social groups were given representation in VDCs. Respondents included both members and non-members of VDCs. Membership status of respondents is shown in Table 4. Fifty two percent of respondents were members and 48 were non-members. Overall membership status of respondents is depicted in Table 4 these

\begin{tabular}{|c|c|c|c|}
\hline \multirow[b]{2}{*}{ Age } & Owners $=213$ & Tenants=182 & Total=395 \\
\hline & $\begin{array}{l}\text { Percentage of group } \\
\text { total }\end{array}$ & $\begin{array}{l}\text { Percentage of group } \\
\text { total }\end{array}$ & Overall percentage \\
\hline $25-34$ & 14 & 11 & 13 \\
\hline $35-44$ & 23 & 22 & 23 \\
\hline $45-54$ & 33 & 39 & 35 \\
\hline $55-64$ & 21 & 19 & 20 \\
\hline \multirow[t]{2}{*}{ Above 65} & 9 & 9 & 9 \\
\hline & 100 & 100 & 100 \\
\hline
\end{tabular}

Table 1: Age of Sampled Respondents.

\begin{tabular}{|c|c|c|c|}
\hline $\begin{array}{c}\text { Education } \\
\text { level }\end{array}$ & $\begin{array}{c}\text { Owners=213 } \\
\text { Percentage of } \\
\text { group total }\end{array}$ & $\begin{array}{c}\text { Tenants=182 } \\
\text { Percentage of } \\
\text { group total }\end{array}$ & Total=395 \\
\hline Illiterate & 12 & 39 & 24 \\
\hline Primary & 9 & 8 & 9 \\
\hline Middle & 16 & 17 & 16 \\
\hline Matric & 23 & 19 & 22 \\
\hline F.A & 19 & 11 & 15 \\
\hline Above F.A & 21 & 6 & 14 \\
\hline Total & 100 & 100 & 100 \\
\hline
\end{tabular}

Table 2: Education of Sampled Respondents.

\begin{tabular}{|l|c|c|c|}
\hline \multirow{2}{*}{ Occupation } & \multicolumn{3}{|c|}{ Strength in percentage } \\
\cline { 2 - 4 } & owners & Tenants & Total \\
\hline Agriculture & 47 & 39 & 43 \\
\hline Government service & 21 & 22 & 22 \\
\hline Business & 21 & 22 & 22 \\
\hline Private jobs & 12 & 6 & 9 \\
\hline Driver & 0 & 3 & 1 \\
\hline Carpenter & 0 & 3 & 1 \\
\hline Labor & 0 & 6 & 3 \\
\hline
\end{tabular}

Table 3: Occupation of Respondents. 
results are in line with SRSP Annual Review [5].

To manage the forestry related natural resources VDCs took a number of steps. These include imparting of training to community members, contact with Forest Department, nursery raising, improved grazing practice, pasture management and tree plantation. VDCs were also involved in identification of needs, preparation of village development plans and implementation and monitoring of project activities. Learning trips of VDCs were also arranged to other areas these results are in line with Taddese and Feyera [6,7].

One of the key responsibilities of VDCs was to impart training to local communities regarding nursery raising, afforestation, reafforestation, and control grazing and pasture management. Duration of training ranged from one to three weeks. On an average $55 \%$ of respondents confirmed that they received training in afforestation and reafforestation. Among those who received training, forty seven percent attended one-week training course, $14 \%$ attended two-week training course and $49 \%$ attended three-week training course. Under the participatory approach it was mandatory for VDCs to prepare Village Land Use Plan (VLUP) under the guidance of Forest Department. Ninety one percent of respondents reported that they had regular contacts with the Forest Department to seek guidance for afforestation, reafforestation, fire control, nursery raising, range management, farm forestry, etc.

About one third of respondents raised nurseries. Most of nurseries were raised during 1995-99. VDCs provided seed for $20 \%$ of nurseries while seed for remaining nurseries was provided by other agencies. Various types of plants were grown in the nurseries. These included Chir (29\%), Eucalyptus (23\%), Acacia (28\%) and Poplar (20\%).

Plantation was the major activity undertaken with the help of VDCs. On an average 57\% of respondents practiced plantation. Species planted are mentioned above. Details of plantation carried out by sampled respondents are given in Table 5 . Hundred percent of respondents were aware of importance of tree plantation. Many were even aware of medicinal plants. Social Forestry Project Malakand/Dir was the main motivating and educating agency for this. Majority of respondents supported the view that VDCs promoted the tree culture

\begin{tabular}{|l|c|c|c|}
\hline \multirow{2}{*}{ Category } & \multicolumn{3}{|c|}{ Membership in percentage } \\
\cline { 2 - 4 } & Owners & Tenants & Total \\
\hline Members & 42 & 64 & 52 \\
\hline Non members & 58 & 36 & 48 \\
\hline Total & 100 & 100 & 100 \\
\hline
\end{tabular}

Table 4: Membership Status of Sampled Respondents.

\begin{tabular}{|l|c|c|c|c|c|c|}
\hline \multirow{2}{*}{ Particular } & \multicolumn{2}{|c|}{ Owners=215 } & \multicolumn{2}{c|}{ Tenants=180 } & \multicolumn{2}{c|}{ Total=395 } \\
\cline { 2 - 7 } & Number & $\mathbf{\%}$ & Number & $\%$ & Number & $\%$ \\
\hline Respondents & 105 & 49 & 120 & 67 & $225=$ & 57 \\
\hline Type of trees Planted & & & & & 225 & 57 \\
\hline 1. Eucalyptus, Acacia, Chirr & 80 & 37 & 105 & 58 & 185 & 47 \\
\hline 2. Poplar & 25 & 12 & 15 & 8.3 & 40 & 10 \\
\hline Number of Trees Planted & & & & & & \\
\hline 1. 1-1000 & 30 & 16 & 15 & 8.3 & 45 & 11 \\
\hline 2. 1001-2000 & 40 & 19 & 65 & 36 & 105 & 27 \\
\hline 3. 2001 \& Above & 35 & 16 & 40 & 22 & 75 & 19 \\
\hline Seed providing Agency & & & & & & \\
\hline 1. DFFW & 10 & 4.6 & 0 & 0 & 10 & 2.5 \\
\hline 2. SFPDM & 25 & 12 & 10 & 5.5 & 35 & 8.9 \\
\hline 3. VDC & 70 & 33 & 110 & 61 & 180 & 46 \\
\hline
\end{tabular}

Table 5: Tree Plantation Carried Out by Sampled Respondents. in the area. These results are in line with Taddese and Feyera [6].

VDCs introduced controlled grazing in the area. Fifty two percent of respondents acknowledged that have controlled grazing system in their villages. Remaining $48 \%$ were practicing free grazing. They were of the opinion that there was no proper way of pasture management. Thirty percent of respondents reported that they were managing their pastures according to needs, and $22 \%$ reported that they were practicing rotational grazing. Respondents who were exercising rotational/ control grazing acknowledged that this practice was due to motivation of VDCs. Details of grazing practices are summarized in Table 6. These results are in line with Shahid [3].

In the past several NRM projects have been launched. Some of these projects were sectoral projects and their emphasis was on conservation through afforestation and improved range management, while others were integrated area development projects. Initially the concept of community participation was not popular in the projects implementations. Subsequently, as per requirements of donor agencies, community involvement through VDCs/CBOs was made integral part of project implementation. For the last two decades most of the foreign funded development projects are community participatory. Over the recent years donor agencies are emphasizing on poverty alleviation and the project managers are required to design the project which inter-alia focuses on the poor and help in poverty reduction. VDCs have been formed under various projects to involve communities in the socioeconomic development activities. Never any serious study has been untaken to evaluate the performance of VDCs. Only some of the VDCs are working satisfactorily. In several cases VDCs are defunct, or just on papers. In some other cases VDCs have been hijacked by vested interest groups. Success of a VDC depends on the composition and commitment of its members, particularly its chairman. If the chairman of a VDC is not a committed person then the working of the VDC is in doldrums.

\section{Conclusions}

Participatory approach has shown partial success in management of forest related natural resources. It has created awareness among communities about the importance and role of natural resources and need for their proper management. There is some success in growing of nurseries, plantation of trees and supervision of forests. There is minor improvement in management of pastures. Success is yet to be achieved in range management, commercialization of medicinal plants and sustainable management of forest related natural resources.

\section{Recommendations}

1. There should be regular programs for education, training and monitoring of VDCs

\begin{tabular}{|c|c|c|c|c|c|c|}
\hline \multirow{2}{*}{ Particular } & \multicolumn{2}{|c|}{ Owners=215 } & \multirow{2}{*}{$\begin{array}{c}\text { Tenants }=180 \\
\text { Number }\end{array}$} & \multirow[b]{2}{*}{$\%$} & \multicolumn{2}{|c|}{ Total=395 } \\
\hline & Number & $\%$ & & & Number & $\%$ \\
\hline Existing Practices & & & & & 225 & 57 \\
\hline 1. Free grazing & 190 & 88 & 0 & 0 & 190 & 48 \\
\hline 2. Control grazing & 25 & 12 & 89 & 100 & 205 & 52 \\
\hline \multicolumn{7}{|c|}{ Type of Pasture Management } \\
\hline 1. Need based & 15 & 7 & 105 & 58 & 120 & 30 \\
\hline 2.Rotational grazing & 10 & 5 & 75 & 42 & 85 & 22 \\
\hline 3. Free grazing & 190 & 88 & 0 & 0 & 190 & 48 \\
\hline
\end{tabular}

Table 6: Grazing Practices and Pasture Management. 
Citation: Haidar Ali, Shafi MM, Siraj M, Himayatullah, Ullah A (2014) Management of Forest Related Natural Resources through Participatory Approach. J Environ Anal Toxicol 4: 237. doi: 10.4172/2161-0525.1000237

Page 4 of 4

2. Credit facilities should be provided for rising of nurseries and commercialization of high value plants.

3. Success of VDCs depends upon the motivation and sense responsibilities of VDCs members. So, extreme care is needed in formulation of VDCs.

4. Special attention should be given to the poor and tenants whose dependence on natural resources is relatively higher than owners and well-offs.

\section{References}

1. Govt. of Pakistan (2010) Agricultural Statistics of Pakistan. Ministry of Food Agriculture and Livestock, Economic Wing, Islamabad.
2. Govt. of Pakistan (2000) Pakistan Agricultural Census. Agricultural Census Organization, Economic Affairs Division, Lahore, Pakistan.

3. Shahid Z (2005) Agro Sector collapsing due to Inept Policies. The daily Frontier Post, Peshawar.

4. Asian Development Bank (2002) Poverty in Pakistan, Issues, Causes and Institutional Responses.

5. SRSP Annual Review 1999-2000 (2001) Sarhad Rural Support Progamme, Peshawar, Khyber Pakhtunkhwa.

6. Taddese W, Feyera S (2008) Sustainable Management and Promotion of Forest Coffee in Bale, Ethiopia.

7. Warner A, McCall K, Garner S (2008) The Role of NTFPs in Poverty Alleviation and Biodiversity Conservation Proceedings of the international workshop on the Theme in Ha Noi, Viet Nam. 